\title{
Expression of Physical Activity in the Elderly: Lithuanian Case
}

\author{
Victoria PiscalKIENe \\ Kaunas University of Applied Sciences. Kaunas, Lithuania \\ viktorija.piscalkiene@go.kauko.lt
}

\begin{abstract}
The research shows that active physical activity ascertains healthy ageing, helps to avoid the risk of falling, prevents from all kinds of physical indispositions, betters psychological state and cognitive characteristics, and helps to avoid diseases such as overweight, etc.

Aim of the research: to assess expression of physical activity in the elderly. Respondents: there were 307 elderly people from various Lithuanian cities and districts who participated in the survey. Methods of research: structured questionnaire. Data were processed using an SPSS program (Statistical Package for Social Sciences, version 19.0). Methods of statistical analysis: descriptive statistics, T-test, Anova test, Spearman's Correlation. The results of the research: The research showed that the most popular forms of physical activity for old people are walking outside $(70.8 \%$ ), housekeeping $(63.4 \%)$, gardening and truck farming $(43.5 \%)$, and playing with grandchildren (25.8\%). Only $25.5 \%$ of respondents ride a bike. Only $7.8 \%$ of respondents jog or use Nordic walking. The least popular forms of physical activity among elderly people are swimming (5.9\%), dancing $(5.2 \%)$ and yoga $(4.6 \%)$ classes. The differences in physical activity forms between people of various ages were defined. $60-74$ year old people ride their bikes $(p=0.011)$ and do some gardening or truck farming more often than older people $(p=0.009)$. When looking for connections between physical activities and falls, it was determined that elderly people who dance tend to fall the least $(\mathrm{p}=0.042)$. The research helped to determine some benefits of physical activity for the health. Nordic walking has the strongest and the best impact on good night sleep. People who dance have indicated the longest duration of sleep. People who were using physical activity forms such as yoga, dancing, jogging, riding a bike and Nordic walking used less medicine during the last three months $(p \leq 0.05)$. There were no significant statistical differences found between body mass index and the form of physical activity used.

Conclusion: Elderly people link physical activity with housework without paying enough attention to it or having an opportunity to go in for sports or to use other forms of active living.
\end{abstract}

Keywords: elderly, physical activity, falls, sleep, Body Mass Index. 


\section{Resumen}

La investigación muestra que realizar una actividad física favorece un envejecimiento saludable, contribuye a evitar el riesgo de caídas, previene todo tipo de trastornos físicos, mejora el estado psicológico y las capacidades cognitivas, y contribuye a evitar enfermedades como el sobrepeso, etc.

Objetivo de la investigación: evaluar la expresión de la actividad física entre personas de la tercera edad. Encuestados: participaron en la encuesta 307 personas de la tercera edad, procedentes de diversas ciudades y distritos de Lituania. Métodos de investigación: cuestionario estructurado. Los datos fueron procesados con el uso del programa SPSS (siglas en inglés de Paquete Estadístico para las Ciencias Sociales, versión 19.0). Métodos de análisis estadístico: estadística descriptiva, test-T, test Anova, correlación de Spearman. Resultados de la investigación: la investigación muestra que las formas más populares de actividad física para las personas mayores son caminar al aire libre $(70,8 \%)$, la realización de las tareas de mantenimiento del hogar $(63,4 \%)$, la jardinería y el cultivo de hortalizas (43,5 \%), así como jugar con los nietos (25,8 \%). Tan solo el 25,5\% de los encuestados monta en bicicleta. Únicamente el 7,8 \% de los encuestados practica el jogging o la marcha nórdica. Las formas menos populares de actividad física entre las personas de mayor edad son la natación $(5,9 \%)$, el baile $(5,2 \%)$ y las clases de yoga $(4,6 \%)$. Se definieron las diferencias en las formas de actividad física entre personas de diversas edades. Las personas de 60 a 74 años montan en bicicleta $(p=0,011)$ y realizan algunas labores de jardinería o de cultivo de hortalizas con mayor frecuencia que las personas de edad superior $(p=0,009)$. Al examinar la relación entre las actividades físicas y las caídas, se determinó que las personas de la tercera edad que practican algún baile tienden a ser las que menos caídas sufren $(p=0,042)$. La investigación contribuyó a determinar algunos beneficios de la actividad física para la salud: la marcha nórdica obtiene los mejores y más sólidos resultados sobre un buen sueño nocturno; las personas que practican algún baile han informado de un sueño más prolongado; las personas que practican actividades físicas como el yoga, el baile, el jogging, montar en bicicleta y la marcha nórdica utilizaron menos medicamentos durante los tres meses anteriores $(\mathrm{p} \leq 0,05)$. No se hallaron diferencias estadísticas significativas entre el índice de masa corporal y la forma de actividad física empleada.

Conclusión: las personas de la tercera edad relacionan la actividad física con la realización de las tareas domésticas, sin prestar demasiada atención a esta cuestión ni teniendo la oportunidad de participar en deportes o de recurrir a otras formas de vida activa.

Palabras clave: tercera edad, actividad física, caídas, sueño, índice de masa corporal.

\section{Introduction}

Ageing of society is humanity's universal problem and is deeply connected with an often physical and emotional discomfort of elderly people, life quality and physical passiveness. It is foreseen that in the beginning of 2030, $28.9 \%$ of Lithuania's inhabitants will be elderly people (60 years old and above) and the situation in the European Union will be similar $-30.4 \%$ of people will be older than 60 . One of the main challenges that we face during society's ageing is to assure that we still have productive members of society, and older people can age in a healthy, independent way. Healthy ageing is defined as an ability to ensure physical, social and emotional health. In other words, it is a solving process of how to enable elderly people to participate in society's social life without experiencing discrimination and to enjoy independence and quality of life (Javtokas, 2008; WHO, 2015).

Low physical activity is one of the most common features of modern society's way of living because domestic technologies, computerizing and the development of communication means have decreased the need to constantly move. $70 \%$ of all deaths in the United States are caused by chronic diseases. The spreading of chronic diseases dramatically grows with age. More than $80 \%$ of people older than 65 years old has at least one chronic disease. Physical activity helps to decrease dying from chronical diseases up to $30 \%$ (arterial hypertension, cardiovascular disease, diabetes, colon and breast cancer). Regular physical activity has a positive influence on the health of various aged people. 
Physical exercises can decrease or even stop depression and chronical diseases which are very common among elderly people. For example, least depression danger was discovered for people who were highly physically active, which means that their aerobic activity lasted not less than 90 minutes a day or 4 hours a week. Furthermore, physical activity unquestionably influences some other aspects of health positively: short memory, comprehension, mood, self-esteem, ability to take care of oneself and move independently, ability to communicate (Warburton, 2010; Chalder, 2012; Zumeras, 2013). According to WHO recommendations in older than 65 years old adults and above, physical activity includes leisure time physical activity, transportation (e.g. walking or cycling), occupational (if the individual is still engaged in work), household chores, playing games, sports or planned exercise, in the context of daily, family and community activities. Adults aged 65 and above should do at least 150 minutes of moderate-intensity aerobic physical activity throughout the week or do at least 75 minutes of vigorous-intensity aerobic physical activity throughout the week or an equivalent combination of moderate and vigorous-intensity activity. Aerobic activity should be performed in bouts of at least ten minutes duration (WHO, 2010).

It is important to mention that a suitable way to keep physical activity for elderly people (especially the ones who are passive and do not move very often) is dog walking and taking care of it in general (Toohey, 2011). It is important to remember that general physical activity (elderly people as well) is displayed in four main life areas (apart from sport itself): in free time, the professional area (if a person is still working), everyday life, and mobility/ transportation area (Zumeras, 2013).

People living in the European Union do not live a physically active life (Special Eurobarometer, Sport and Physical activity, 2014). The main findings of the Eurobarometer survey on sport and physical activity are as follows: the majority of the respondents $(59 \%)$ say that they never exercise or play sport. The findings for the countries show that citizens in the Northern part of the EU are the most physically active. The proportion that exercises or plays sport at least once a week is $70 \%$ in Sweden, $68 \%$ in Denmark, $66 \%$ in Finland, $55 \%$ in the Netherlands. Most respondents who never exercise or play sport can be found in Bulgaria (78 \%), Malta (75\%), Portugal (64\%), Romania (60\%), Italy (60\%), Poland (52\%), Lithuania (46\%) and Spain (44\%).
After conducting a research in healthy living among elderly people in Lithuania, it was discovered that only $20.1 \%$ of older people are physically active (this means that they do some activities individually, do exercise or jog). The majority of respondents, especially the ones living in the countryside, did not know or did not understand how physical activity could be beneficial for their health. They think that the only way to better their health is by resting and drinking medicine (Valintelienè, 2012). Only $13 \%$ of elderly people exercise every day, and $29 \%$ a couple of times a week. Every third respondent estimated their physical activity as satisfactory, $37 \%$ as bad. The respondents think that they lack information about health strengthening and benefits in old age. Another research made in Lithuania showed that people older than 60 are extremely passive because only $32.7 \%$ of such age respondents claim to be doing physical activity during their working hours and only $12.5 \%$ in their free time (Valintelienè, 2012). According to the data of a research about the elderly people way of living in Lithuania carried out in 2010 (European Project CHANGE), only $20.1 \%$ of older people have an active lifestyle and most of them live in big cities, the $82.2 \%$. Elderly people who live in the countryside were more into singing, did physical work or used bikes but did not do any other physical exercise (Juozulynas, 2010). Since 2002, the Lithuanian Sport Department is conducting a research (every 5 years) and according to the data from 2011, $60 \%$ of elderly people do not exercise at all (Zumeras, 2013). Elderly women who are physically active are psycho-physically healthier than physically inactive women. Physically passive women have high blood pressure and often get ill with all kinds of heart diseases. Physical activity influences elderly women's cognitive function positively. Data from research showed that $42.9 \%$ of physically active women have good blood pressure and only $14.3 \%$ of women who do not do physical activity have normal blood pressure. According to the data, $48.6 \%$ of women who do not exercise and only $24.3 \%$ who exercise complained about having insomnia. $44.3 \%$ physically active women consider themselves as totally healthy and only $22.1 \%$ of physically passive women do the same. Respondents took Veston test before physical activity and after and it was clear that elderly women who did exercise finished the test faster and it was more accurate (Klizas, 2012).

The Lithuanian situation shows that the least active are elderly people who are sick or take medica- 
tion, also the ones who are less educated or get lower income, besides the ones who live in the countryside. According to the data of health education received from the Lithuanian government in 2012, only $2.1 \%$ of people who participated in health education events were elderly people (60 years old and above). That is why it is important to encourage elderly people in physical activities and to organize health education events for elderly people (Plan of assuring healthy ageing in 2014-2023, Ministry of Health, Lithuania).

Lithuania has not got a system for observing the physical activity of its inhabitants but there are many questionnaires made around the world to evaluate physical activity. On the other hand, it is difficult to interpret and often impossible to compare with the index of physical activity in another country when you research people's physical activity with different measures or research attitudes towards different forms of physical activity. Lithuanian people are not physically active enough. Physical activity (together with other factors of healthy living) can give elderly people a real opportunity to lengthen the time of their independent living and to decrease functional limitation and social insulation. The programs of encouraging physical activity should be oriented to elderly people who are not physically active and live in the countryside.

\section{Research}

Aim of the research: to assess expression of physical activity in the elderly.

Methods of the research: structured questionnaire. Data were processed using an SPSS program (Statistical Package for Social Sciences, version 19.0). Methods of statistical analysis: descriptive statistics, T-test, Anova test, Spearman Correlation Coefficient.

Sample: there were 307 elderly people (from 60 years old and older) from various Lithuanian cities and districts who participated in the survey. The majority of people examined (77\%) were 60-74 year old. The minority (21\%) of people who participated in the survey were 75-90 years old and only $2 \%$ were older than 90 years old. Among the people who participated, there were $66 \%$ women and $34 \%$ men. Respondents lived in various districts: in the city $(59 \%)$, in the settlement $(17.9 \%)$ and in the countryside $(23.1 \%)$.

Table 1. Characteristics of respondents

\begin{tabular}{|l|c|}
\hline \multicolumn{1}{|c|}{$\begin{array}{c}\text { Characteristics of } \\
\text { respondents }\end{array}$} & N (\%) \\
\hline Age & $238(77.5 \%)$ \\
\hline $60-74$ & $65(21.2 \%)$ \\
\hline $75-90$ & $4(1.3 \%)$ \\
\hline More than 90 & $203(66.1 \%)$ \\
\hline Gender & $104(33.9 \%)$ \\
\hline Female & \\
\hline Male & $181(59 \%)$ \\
\hline Living location & $55(17.9 \%)$ \\
\hline City & $71(23.1 \%)$ \\
\hline Settlement &
\end{tabular}

\section{Results}

This article presents the results of elderly people's physical activity. Physical activity will be compared with socio-demographic data, and data which reveal the physical activity influence on physical health will be presented.

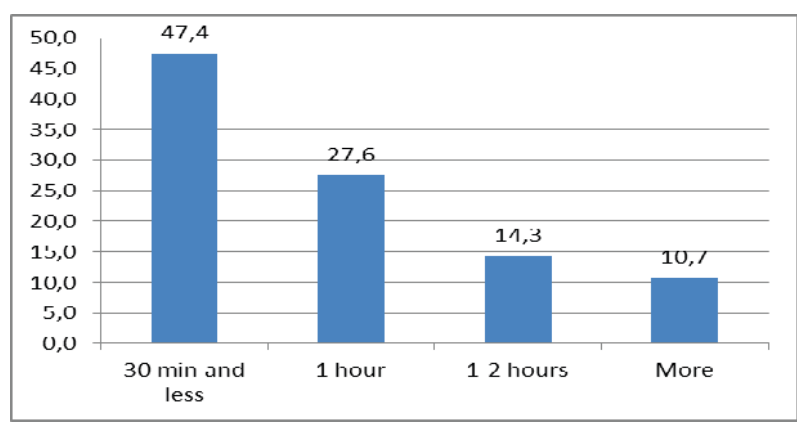

Figure 1. Elderly people spending time on physical activity/day

The research showed that almost half of the people older than 60 who participated in this research 
spend 30 minutes (or less) a day exercising. This means that only every second person spends not less than 30 minutes a day exercising, as the WHO (2016) recommends. After carrying out a test of comparing average (Anova) there was no significant statistical difference found between people who lived in different locations (city, countryside) and physical activity.

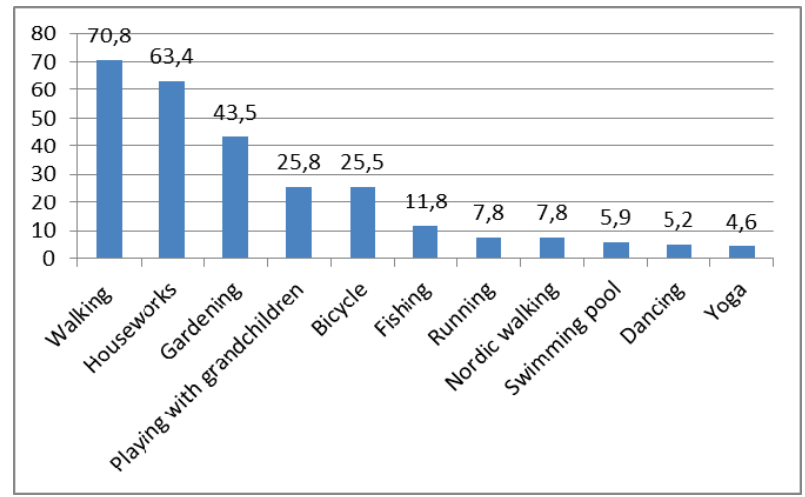

Figure 2. Physical activity types

One of the most popular forms of physical activity among people older than 60 years old is walking $(70.8 \%)$. Domestic work, which is one of the possible forms of exercising, was named by $2 / 3$ respondents $(63.4 \%)$. Less than half of the people who participated in this research do gardening and truck farming $(43.5 \%)$. It is very interesting that a quarter $(25.8 \%)$ of respondents named playing with grandchildren as one of the physical activity forms. A similar number of people said they regularly rode a bike (Figure 2). The least popular forms of physical activity are jogging (7.8\%), Nordic walking $(7.8 \%)$, swimming $(5.9 \%)$, dancing $(5.2 \%)$ and yoga $(4.6 \%)$.

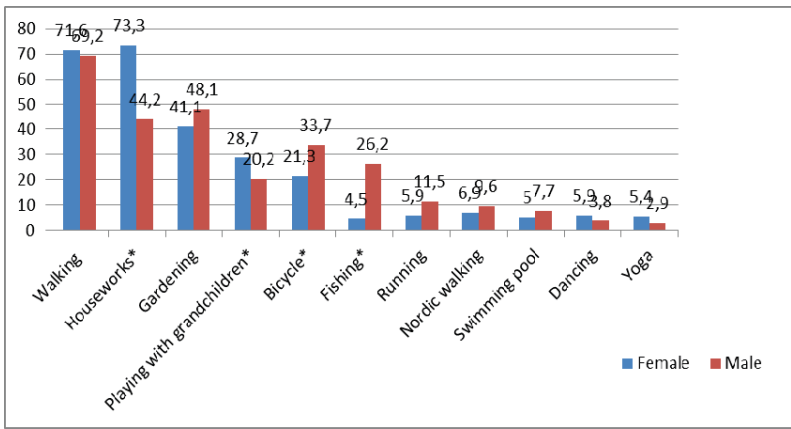

Figure 3. Physical activity types by gender
There were significant statistical differences found, which showed that forms of physical activity are connected. People who ride a bike also tend to use other forms of physical activity, such as: walking $(\mathrm{R}=0.145 ; \mathrm{p}=0.011)$, jogging $(\mathrm{R}=0.155 ; \mathrm{p}=0.007)$, pool swimming $(\mathrm{R}=0.141 ; \mathrm{p}=0.014)$, gardening/ truck farming $(\mathrm{R}=0.0244 ; \mathrm{p}=0.000)$ and fishing $(\mathrm{R}=0.321 ; \mathrm{p}=0.000)$. People who do Nordic walking are also more likely to choose jogging $(\mathrm{R}=0.134$; $\mathrm{p}=0.019)$, yoga $(\mathrm{R}=0.285 ; \mathrm{p}=0.000)$ and swimming in a pool $(\mathrm{R}=0.185 ; \mathrm{p}=0.001)$. People who spend more time playing with their grandchildren tend to go for a walk more often $(\mathrm{R}=0.203 ; \mathrm{p}=0.000)$ and link their physical activity with domestic work: gardening/truck farming $(\mathrm{R}=0.230 ; \mathrm{p}=0.000)$ and keeping the house $(\mathrm{R}=0.283 ; \mathrm{p}=0.000)$.

There were significant statistical differences found, which let us claim that physical activity of men and women differ by the kind of activity (Figure 3). When doing domestic work, men are more passive than women ( $\mathrm{T}$ test, $\mathrm{p} \leq 0.05$ ). $77.3 \%$ of women consider domestic work as one of the physical activity forms. It is possible to think that women $(28.7 \%)$ pay more attention to taking care of their grandchildren (and actively playing with them ( $\mathrm{T}$ test, $\mathrm{p} \leq 0.05))$ than men $(20.2 \%)$. The physical activity form which requires less motion is fishing. $26.2 \%$ of men choose it and only less than half their percentage of women ( $\mathrm{T}$ test, $\mathrm{p} \leq 0.05$ ). Other forms of physical activity between men and women did not come up during the research.

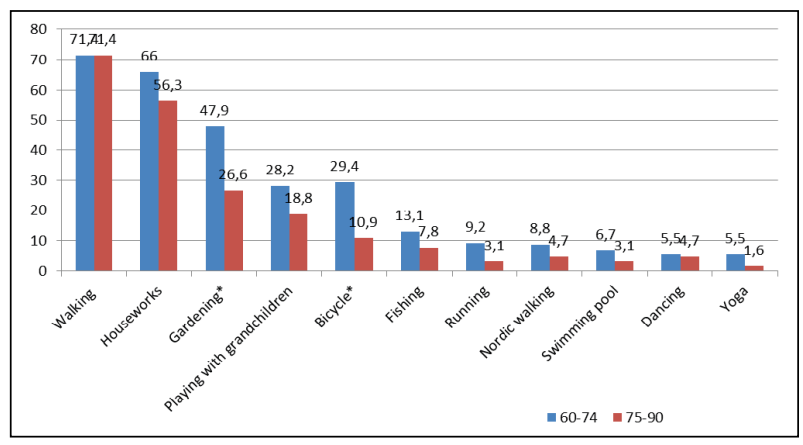

Figure 4. Physical activity types by age

It was discovered that physical activity tends to decrease with age (Figure 4). Gardening and truck farming is most popular among 60-74-year old people ( $T$ test, $p \leq 0.05$ ). Riding a bike is one of the physical activity forms that 64-74-year old people 
use ( $T$ test, $\mathrm{p} \leq 0.05$ ). Only two kinds of physical activity are used by people older than 90 - walking and domestic work. But it wouldn't be fair to estimate physical activity of such old people by the percentage of age expression because only 4 people (older than 90 years old) participated in the research.

In many cases, the results of various researches show that physical activity is connected to good physical and psychological state. This article presents data about falls, sleep and a good Body Mass Index (BMI).

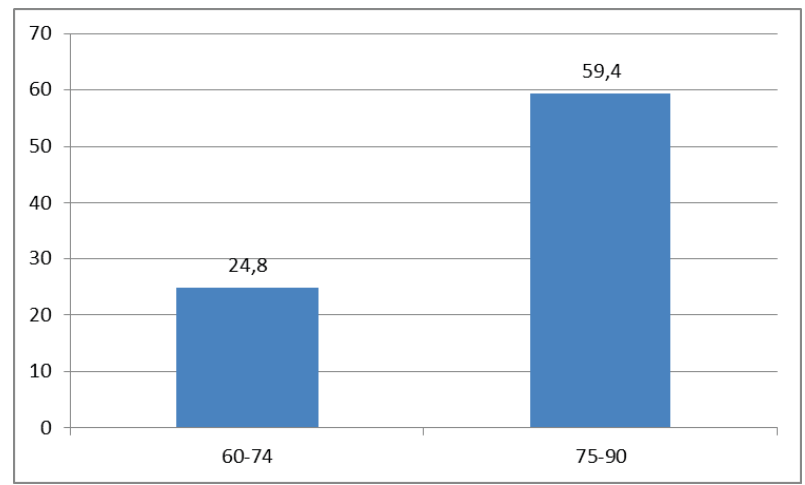

Figure 5. Falls by age groups

Almost every third person who participated in the research experiences falls $(28.5 \%)$. It was discovered that falling is a frequent problem among elderly people (Figure 5). In a group of 60-74-year olds, $24.8 \%$, people fall, when in a group of $75-90$-year olds, people fall twice as often. Almost $2 / 3$ people of such age suffer falls (Anova, $\mathrm{p} \leq 0.05$ ). People of such age were not included when making the statistical calculation because it would not be correct, since only a couple of people such age participated in the research and none of them were able to walk because of their health condition. When looking for connections between physical activities and falls, it was determined that elderly people who dance tend to fall the least $(\mathrm{p} \leq 0.05)$.

It was interesting to find out how physical activity is connected with sleep quality at night by counting the sleep length. On average, elderly people sleep 7.5h during the night (Std. Deviation 1.630). The ones who walk with Nordic walking sticks have an average sleep of 7.6 hours during a day and those who do not, 6.9 hours a day (Anova test, $\mathrm{p} \leq 0.05$ ). People who dance have indicated the longest du- ration of sleep ( 8 hours), which lets us claim that dancing is an effective measure to ensure a good night sleep.

Some other facts also prove that physical activity has a great impact on patients' sleep. People who jog $(\mathrm{p}=0.088)$, ride a bike $(\mathrm{p}=0.008)$, do Nordic walking $(\mathrm{p}=0.023)$, gardening $(\mathrm{p}=0.024)$, go dancing $(0=0.043)$ and fishing $(\mathrm{p}=0.038)$ do not use drugs to better their sleep.

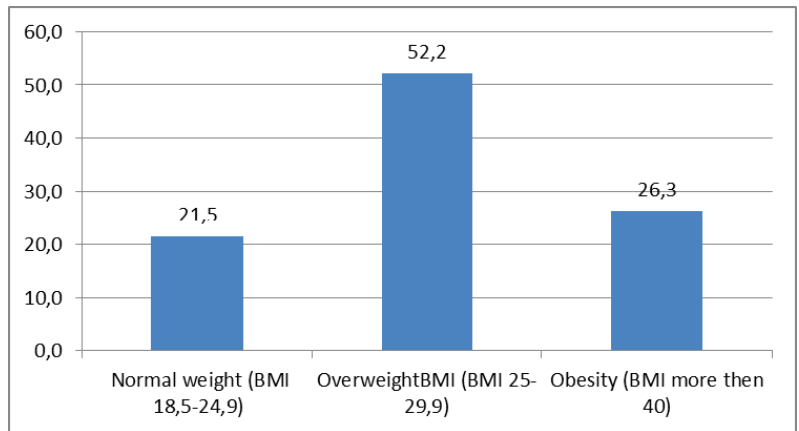

Figure 6. Body Mass Index in elderly and old age groups

The research showed that only $21.5 \%$ of elderly people who participated in the research have the right body mass index, when $\mathrm{BMI}=18.5-24.9$. Other $52.2 \%$ are overweight and $26.3 \%$ are obese (Figure $6)$. There were no significant statistical differences found between body mass index and the form of physical activity used.

\section{Conclusions}

The research shows that active physical activity ascertains healthy ageing, helps to avoid the risk of falling, prevents from all kinds of physical indispositions, betters psychological state and cognitive characteristics, helps to avoid diseases such as overweight, etc.

After summarizing the data of the research, we can claim that the physical activity of Lithuanian people is insufficient, especially among elderly people. 
Elderly people link physical activity with housework without paying enough attention to it or having an opportunity to go in for sports or use other forms of active living. Dances and Nordic walking are very effective forms of keeping good health in older age, and they also help to avoid risk of falls and improve the quality of sleep.

\section{Acknowledgements}

The author would like to thank the general practice nursing students of Kaunas University of Applied Sciences for helping to carry out the questionnaire by questioning their grandparents and relatives.

\section{References}

1. Chalder M., Wiles N. J., Campbell J., Hollinghurst S. P., Searle A., Haase A. M., Taylor A. H., Fox K. R. et al. (2012). A pragmatic randomised controlled trial to evaluate the cost-effectiveness of a physical activity intervention as a treatment for depression: the treating depression with physical activity (TREAD) trial. Health Technol Assess, 16 (10): 158-164.

2. CHANGE (2008). Lifelong learning programme EU project care of health advertising newgoals for elderly people.

3. Healthy aging assurance plan in Lithuania 2014-2013. Order of Lithuanian Minister of Health (2014). Lithuanian Ministry of Health. https://www.e-tar.lt/portal/legalAct.html?documentId=85fb0c200d7311e4adf3c8c5d7681e 73

4. Javtokas Z., and Mačiūnas E. (2008). Pagyvenusių žmonių sveikatos stiprinimas. Vilnius: Valstybinis aplinkos sveikatos centras.

5. Juozulynas A., Savičiūtė R., Butikis M., Jurgelènas A., Filipavičiūtė R., Cozzolino M. ir kt. (2010). Vyresnio amžiaus žmonių sveikos gyvensenos ypatumai. Sveikatos mokslai, 5: 3519-3523.

6. Kalibatienė D., and Šalaviejūtė A. (2005). Slaugos poreikių namuose ịvertinimas. Slauga. Mokslas ir praktika, 6(102): 3-6.

7. Klizas S., Sipavičienė S., Klizienè I., and Pliauga V. (2012). Effect of Physical Activity for Psychophysical Health of Elderly Women. Medicine Theory and Practice, 18 (3): 267-272.

8. National Center for Chronic Disease Prevention and Health Promotion (2014). http://www.cdc.gov/ chronicdisease/overview/index.htm.

9. Piscalkiene V., Gintiliene M., Rutkauskiene L., and Kubaitis V. (2014). Balance changes of dancing and not-dancing Lithuanian folk dances: posturographic assessment, Health Science, 24( 6):17-24.

10. Special Eurobarometer, Sport and Physical activity, 2014. http://ec.europa.eu/health/nutrition_physical_ activity/docs/ebs_412_en.pdf

11. Statistics of Lithuania (2015). http://db1.stat.gov.lt/statbank/SelectTable/Omrade0.asp?PLanguage=1

12. Toohey A. M., and Rock M. J. (2011). Unleashing their potential: a critical realist scoping review of the influence of dogs on physical activity for dog-owners and non-owners. Int J Behav Nutr Phys Act, 8: 46-53.

13. Valintelienè, R., Varvuolienè R., and Kranauskas A. (2012). Lietuvos gyventoju fizinis aktyvumas, vertinant GPAQ metodu. Visuomenès sveikata, 4(59): 67-74.

14. Warburton D., Charlesworth S., Ivey A., Nettlefold L., and Bredin S. (2010). A systematic review of the evidence for Canada's Physical Activity Guidelines for Adults. Int J Behav Nutr Phys Act, 7 (39): 2-22.

15. WHO Global Recommendations on Physical Activity for Health. (2010): 23-29.

16. World Health Organisation (2015). http://www.who.int/ageing/en/

17. Zumeras R. (2013). Pagyvenusių žmonių fizinis aktyvumas ir sveikata. Vilnius: Sveikatos mokymo ir ligu prevencijos centras. 